\title{
Problematika pelaksanaan bimbingan dan konseling di SMA: A systematic literature review (SLR)
}

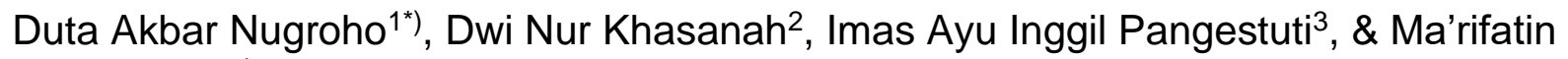 \\ Indah Kholili ${ }^{4}$ \\ Universitas Sebelas Maret ${ }^{1234}$ \\ *) Alamat korespondensi: Jl. Ir Sutami No.36 A, Surakarta, Jawa Tengah, 57126, Indonesia, E-mail: \\ dutakbrn@student.uns.ac.id
}

\begin{abstract}
Article History: Received: 15/06/2021; Revised: 27/06/2021; Accepted: 27/06/2021; Published: 30/06/2021
\end{abstract}

How to cite: Nugroho, D.A., Khasanah, D.N. Pangestuti, I.A.I., \& Kholili, M.I. (2021). Problematika pelaksanaan bimbingan dan konseling di SMA: A systematic literature review (SLR). Teraputik: Jurnal Bimbingan dan Konseling, 5(1), pp. 87-96. DOI: 10.26539/teraputik.51647

\begin{abstract}
Abstrak: Tujuan penelitian ini adalah untuk mengumpulkan dan menganalisa berbagai artikel terkait dengan Problematika Pelaksanaan Bimbingan dan Konseling di SMA.Penelitian ini menggunakan metode Systematical Literature Review (SLR) dengan teknik analisis data metasintesis. Dalam pelaksanaan program Bimbingan dan Konseling di sekolah, Guru Bimbingan dan Konseling sebagai penganggung jawab yang berkolaborasi dengan seluruh pihak (stakeholder) mengalami berbagai problematika, yaitu; tidak memperoleh proporsi waktu mengajar yang optimal, tidak ada kerjasama dengan pihak lain di sekolah, rendahnya sosialisasi Bimbingan dan Konseling oleh guru kepada perserta didik, terdapat sekolah yang masih menerapkan Bimbingan dan Konseling Pola 17+, adanya persepsi negatif dari siswa sehingga takut untuk menemui guru, dan belum tersedianya fasilitas layanan secara optimal di sekolah. Melihat pada berbagai problematika tersebut, saran untuk penelitian selanjutnya adalah untuk melakukan upaya penanganan melalui pelaksanakan program Bimbingan dan Konseling yang komprehensif di mana stakeholder dilibatkan di dalamnya untuk mencapai tujuan Bimbingan dan Konseling komprehensif itu sendiri.
\end{abstract}

Kata Kunci: Problematika, Pelaksanaan, Bimbingan dan Konseling

Abstract: The purpose of this study is to collect and analyze various articles related to the Problems of Implementation of Guidance and Counseling in Senior High Schools. This study uses the Systematic Literature Review (SLR) method with meta-synthetic data analysis techniques. In the implementation of the Guidance and Counseling program on schools, the Guidance and Counseling Teacher as the person in charge who collaborates with all parties (stakeholders) experiences various problems, such as no optimal enough proportion teaching time, no colaboration with other party in school, low socialization of Guidance and Counseling by teachers to students, some schools that are still apply Bimbingan dan Konseling Pola 17+, negative perceptions from students that make them afraid to meet teachers, and the unavailability of optimal service facilities in schools. Looking at these various problems, suggestions for further research are to make efforts to handle it through the implementation of a comprehensive Guidance and Counseling program where stakeholders are involved in it to achieve the goals of comprehensive Guidance and Counseling itself.

Keywords: Problematic, Implementation, Guidance and Counseling

\section{Pendahuluan}

Bimbingan dan konseling hadir pertama kali pada setting sekolah di Indonesia pada 1960 dengan istilah Bimbingan dan Penyuluhan. Pemikiran ini diawali dari hasil konferensi Fakultas Keguruan dan IImu Pendidikan (FKIP), yang kemudian berubah namanya menjadi IKIP di Malang. Bimbingan dan Penyuluhan kemudian dimasukkan pada kurikulum Sekolah Menengah Atas (SMA) pada tahun 1975 setelah dibentuk Proyek Perintis Sekolah Pembangunan (PPSP) pada 8 IKIP di Indonesia yang kemudian menghasilkan "Pola Dasar Rencana dan Pengembangan Bimbingan dan Penyuluhan" (Zamroni \& Rahardjo, 2015).

Di Indonesia, bimbingan dan Konseling yang telah hadir selama lebih dari 35 tahun, mengalami banyak lika-liku perubahan. Sebagaimana yang dijelaskan Zamroni \& Rahardjo (2015), sampai tahun 1993 Bimbingan dan Penyuluhan berlangsung dengan tidak jelas di 
sekolah, bahkan muncul stigma buruk bahwa siswa yang pergi ke BP adalah siswa yang bermasalah. Pandangan ini terus berlangsung hingga pada 1993, muncul SK Menpan No.83 yang memuat Jabatan Funsional guru dan Angka Kreditnya, dimana mengatur pula mengenai BK. SK Menpan ini kemudian lebih jelas dijabarkan pada SK Mendikbud No. 025/1995.

Layanan terhadap peserta didik Indonesia yang diberikan oleh penggiat ilmu bimbingan dan konseling ini kini memiliki posisi yang semakin mantap setelah ditetapkannya Permendikbud No. 11 Tahun 2014 yang menyatakan bahwa BK adalah bagian yang dapat dipisahkan dari pendidikan Indonesia. Hal ini didukung pula dengan pendapat Prayitno (2004) Bimbingan dan Konseling adalah bagian integral dari pendidikan.

BK di Indonesia telah mengalami perkembangan dari sebelumnya populer akan pola 17 Plus (17+) menjadi pola BK Komprehensif. Depdiknas (2008) mengemukakan bahwa telah terjadi pergeseran paradigma pendekatan BK, dari yang sebelumnya berorientasi remedial, klinis, serta terpusat (tradisional) menjadi pendekatan yang berorientasi pada perkembangan dan preventif.

Bimbingan dan Konseling Komprehensif adalah program BK yang pelaksanaannya dilakukan secara utuh, di mana pelayanan tidak lagi difokuskan pada upaya kurasi namun lebih pada upaya pengembangan potensi siswa secara optimal dan upaya preventif yang dapat dilakukan terkait permasalahan yang mungkin akan dihadapi peserta didik. Sebagaimana yang dijelaskan Sugiyo (Bhakti, 2017) bahwa BK komprehensif adalah rangkaian rancangan kegiatan atau aktifitas konselor yang ditujukan guna memberi bantuan pada klien untuk upaya pengembangan diri seoptimal mungkin. Lebih lanjut, Suherman (Bhakti, 2017) menjelasakan bahwa dalam BK komprehensif harus diperhatikan (1) Ruang lingkup yang menyeluruh; (2) Dirancang untuk lebih berorientasi pada pencegahan; dan (3) Tujuannya adalah pengembangan potensi peserta didik.

Gysbers dan Henderson (2016) mengemukakan bahwa terdapat 5 premis dasar dalam pelaksanaan program BK komprehensif, diantaranya: (1) Bimbingan dan konseling adalah suatu program; (2) Program bimbingan dan konseling adalah pengembangan dan komprehensif; (3) Program bimbingan dan konseling menampilakan pendekatan tim; (4) Program bimbingan dan konseling dikembangkan melalui proses sistematis dari perencanaan, perancangan, pelaksanaan, evaluasi, dan pengembangan; (5) Program bimbingan dan konseling telah membentuk kepemimpinan. Gysbers dan Henderson turut mengemukakan bahwasannya BK komprehensif diterapkan di sekolah melalui 5 tahapan pengembangan yang sistematis, diantaranya; perencanaan (planning), perancangan (desaining), pelaksanaan (implementing), evaluasi (Evaluation), dan pengembangan (Enhancing) dengan kajian yang mendalam dan tata cara yang benar sesuai yang ia sarankan. Dari kelima tahapan ini, tahap pelaksanaan (implementing) menjadi kajian yang menarik untuk dibahas. Tahap pelaksanaan sejatinya merupakan hasil penerapan dari tahap sebelumnya yaitu perencanaan dan perancangan. Dalam melaksanakan tahap pelaksanaan, Gysbers dan Henderson menyarankan untuk selalu memperhatikan 3 sumber daya guna memaksimalkan hasil yang diperoleh. Ketiga sumber tersebut adalah sumber daya finansial, sumber daya personil, dan sumber daya politik.

Mengetahui bagaimana pelaksanaan program BK komprehensif penting untuk dilakukan, mengingat pada jenjang pendidikan SMA, BK berperan sangat krusial pada pengembangan potensi peserta didik. Terlebih, jenjang SMA merupakan jenjang pendidikan pertama dimana Bimbingan dan Konseling dimasukkan pada kurikulum pendidikan di Indonesia, yang berarti pula bahwa pelaksanaan BK di SMA telah berlangsung paling lama dibandingkan dengan jenjang pendidikan lain.

\section{Metode}

Penelitian ini menggunakan jenis penelitian $A$ Systematical Literature Review (SLR). Systematical literature review adalah jenis metode penelitian yang berusaha melakukan identifikasi, evaluasi, serta interpretasi terhadap keseluruhan hasil penelitian yang terkait dengan pertanyaan penelitian, topik, atau fenomena tertentu yang menjadi perhatian (Kitchenham, 2004). Systematical literature review akan sangat bermanfaat untuk melakukan sintesis dari berbagai hasil penelitian yang relevan, sehingga fakta yang disajikan kepada penentu kebijakan menjadi 
lebih komprehensif dan berimbang (Siswanto, 2010). Review penelitian literatur dilakukan untuk berbagai tujuan, diantaranya adalah untuk memberikan latar belakang teori untuk penelitian selanjutnya, mempelajari luasnya penelitian mengenai suatu topik yang menarik, atau menjawab pertanyaan praktis dengan memahami apa penelitian yang ada katakan tentang masalah tersebut (Ocoli \& Schabram, 2010).

Systematical literature review dalam penelitian ini dilakukan dengan melakukan penghimpunan artikel-artikel Bimbingan dan Konseling yang dipublikasikan mulai tahun 2011 hingga tahun 2019. Jumlah artikel awal yang diperoleh pada penghimpunan data mencapai 24 artikel yang kemudian direduksi berdasarkan kriteria (1) Pelaksanaan Progam Bimbingan dan Konseling (2) Kesesuaian dengan fokus penelitian, (3) Kesesuaian dengan jenjang Pendidikan SMA, sehingga hanya dianalisis 20 Jurnal. Artikel diperoleh dari jurnal-jurnal bimbingan dan konseling serta jurnal pendidikan, baik berupa jurnal nasional maupun jurnal internasional. Artikel dikumpulkan dari Jurnal: Insight: Jurnal Bimbingan dan Konseling Islam, Jurnal IImiah Mahasiswa Bimbingan dan Konseling, Jurnal Ilmiah Konseling, Jurnal Administrasi Pendidikan Ekonomi Akuntansi FKIP UIR, Jurnal Administasi Pendidikan, Jurnal of Education and Instruction, Jurnal Manajemen Pendidikan, Jurnal Bimbingan dan Konseling, Jurnal Bimbingan dan Konseling Terapan, Jurnal Bimbingan Konseling, Jurnal Bimbingan Konseling Indonesia, Jurnal BK UNESA, Jurnal Kajian Bimbingan dan Konseling, Skirpsi : Elin, Purwani (2017) Kendala Guru Bimbingan dan Konseling dalam Pelaksanaan Layanan Informasi di SMA Negeri 7 Kerinci. Sarjana thesis, STKIP PGRI SUMATERA BARAT dan Buku : Developing \& Managing Your School Guidance \& Counseling Program ( $\left.5^{\text {th }} \mathrm{Ed}\right)$.

Prosedur penelitian systematic literature review dengan pendekatan kualitatif dilaksanakan dengan mengikuti langkah-langkah menurut Francis \& Baldesari (2006) terdeskripsikan dalam tabel dibawah ini.

Pada Tabel Langkah Prosedur Penelitian Systematical Literature Review Problematika Pelaksanaan Program Bimbingan dan Konseling di SMA.

Tabel 1. Prosedur Penelitian

Langkah penelitian menurut Francis

\& Baldesari (2006)

1) Memformulasikan pertanyaan penelitian (formulating the review question)

\section{Langkah yang dilakukan peneliti}

a) Merumuskan pertanyaan penelitian yang difokuskan pada problematika pelaksanaan program BK peserta didik di jenjang Pendidikan SMA.

b) Membuat pertanyaan berikutnya yaitu upaya yang dilakukan oleh guru BK / peneliti sebelumnya dalam mengatasi permasalahan tersebut.

2) Melakukan pencarian literatur systematic review (conducting a systematic literature search)

a) Melakukan pencarian literatur di berbagai jurnal.

b) Pencarian difokuskan pada jurnal-jurnal BK serta jurnal pendidikan baik nasional maupun internasional.

3) Melakukan skrining dan seleksi artikel penelitian yang cocok (screening and selecting appropriate research articles)

Proses skrining dan seleksi dilaksanakan dengan memperhatikan tujuan serta rumusan pertanyaan penelitian yaitu :

Artikel yang menyajikan data permasalahan bimbingan dan konseling khususnya pada pelaksanaan program BK di SMA.

4) Melakukan analisis dan sintesis temuan-temuan kualitatif (analyzing and synthesizing qualitative)

Proses analisis dilakukan dengan menyusun temuan dari masing-masing artikel, kemudian melakukan perbandingan antar masing-masing artikel tersebut. 


\begin{tabular}{|c|c|c|}
\hline 5) & $\begin{array}{l}\text { Memberlakukan kendali mutu } \\
\text { (maintaining quality control) }\end{array}$ & $\begin{array}{c}\text { Kendali mutu dilakukan dengan } \\
\text { melakukan konsultasi kepada dosen BK. }\end{array}$ \\
\hline 6) & $\begin{array}{l}\text { Menyusun laporan akhir } \\
\text { (presenting findings) }\end{array}$ & $\begin{array}{l}\text { Laporan akhir dilaksanakan dengan cara } \\
\text { menulis artikel hasil penelitian yang kemudian } \\
\text { dipublikasikan. }\end{array}$ \\
\hline
\end{tabular}

Proses analisis data dalam penelitian ini menggunakan metode meta-sintesis. Systematical literature review terdapat dua jenis metode yaitu metode meta-analisis dan metasintesis (Siswanto, 2010). Pada penelitian ini menggunaka teknik analisis datra meta-sintesis dengan melakukan integrasi data untuk mendapatkan teori maupun konsep baru atau tingkatan pemahaman yang lebih mendalam dan menyeluruh (Perry \& Hammond, 2002). Meta sintesis bertujuan untuk menjawab pertanyaan penelitian dengan cara merangkum berbagai hasil penelitian.

\section{Hasil dan Diskusi}

Hasil dari penelitian ini menunjukkan bahwa dalam pengembangan program Bimbingan dan Konseling khususnya pada tahap pelaksanaan masih terdapat banyak problematika hingga saat ini. Masalah yang sampai saat ini masih bisa ditemui yaitu Guru BK yang tidak memperoleh jam masuk kelas untuk melaksanakan layanan klasikal dimana hanya diberikan jika ada guru Matapelajaran yang berhalangan mengajar serta program Bimbingan dan Konseling yang hanya dilaksanakan oleh konselor saja tanpa ada kerjasama dengan pihak lain (Purwaningrum, 2018). Kedua permasalahan tersebut sudah berjalan cukup lama bahkan sampai saat ini pun masih sering dijumpai di lapangan. Terkait kedua permasalahan tersebut, peneliti memberikan alternatif penyelesaian yaitu menggunakan pedoman program Bimbingan dan Konseling Komprehensif dalam pelaksanaan layanan BK di sekolah agar dapat mencapai upaya membantu perkembangan peserta didik dan program yang memandirikan.

Problematika lain terdapat dalam pelaksanaan Program BK di sekolah diungkapkan oleh Wiryosutomo (Permana, 2015) tentang rendahnya sosialisasi bimbingan dan konseling oleh Guru BK kepada peserta didik, sehingga memengaruhi persepsi mereka terhadap kompetensi kepribadian dan kinerja konselor dengan rendahnya minat peserta didik terhadap layanan BK yang sudah ada. Problematika lain diungkapkan oleh Permana (2015) tentang pelaksanaan layanan BK di MAN 2 Banjarnegara. Peneliti mengungkapkan bahwa problematika yang sering terjadi di sekolah MAN adalah kurangnya jam untuk bimbingan dan konseling sehingga kurang dapat memaksimalkan program layanan dan rasio Guru BK dan siswa yang tidak sesuai dengan standar ideal. Meskipun begitu peneliti mengungkapkan bahwa di sekolah MAN 2 Banjarnegara sudah cukup baik dalam melaksanakan program Bimbingan dan Konseling secara komprehensif.

Penelitian mengenai problematika dalam pelaksanaan program BK juga diungkapkan oleh Putri, Hastuti \& Nurhuda (2018) di SMAN 1 Peranap. Penelitian tersebut menunjukkn beberapa problematika dalam pelaksanaan program BK yaitu: 1) layanan BK belum dilaksanakan secara terpogram; 2) kurangnya komitmen Guru BK untuk meningkatkan kompetensi profesional dan pemahaman terhadap karakteristik professional serta kurangnya tenaga profesional dalam pelaksanaan layanan BK; 3) Koordinasi antara Guru BK, Kepala Sekolah dan stake holder sekolah yang masih rendah; 4) rendahnya minat siswa terhadap layanan BK yang ada. Puspitaningrum, Dahlan \& Widiastuti (2013) penelitian terhadap pelaksanaan salah satu komponen program BK yaitu layanan dasar di SMA Kota Metro juga mengungkapkan bahwa terdapat problematika pada layanan klasikal dimana Guru BK tidak memperoleh jam masuk kelas di setiap pekannya sehingga layanan tidak terprogram dengan baik karena layanan klasikal hanya diberikan ketika terdapat masalah dan ketika ada jam kosong saja.

Problematika dalam pelaksanaan salah satu komponen program BK juga terjadi di SMA N 7 Kerinci dalam pelaksanaan layanan infomasi (Purwani, Nita \& Monalisa, 2017). Hambatan yang ditemui oleh Guru BK diakibatkan oleh faktor internal dan eksternal. Faktor internal terdiri dari kurangnya kompetensi Guru BK dalam melakukan need assessment dan kurangnya kemampuan Guru BK dalam koordinasi dengan stake holder sekolah serta dalam menyusun 
program dan evaluasi layanan informasi. Sedangkan, untuk faktor eksternal yaitu kurangnya fasilitas yang memadai untuk pelaksanaan layanan dan tidak adanya alokasi waktu khusus untuk Guru BK dalam melaksanakan layanan informasi.

Hal yang sama juga diungkapkan oleh Mauliza, Dahliana \& Martunis (2018) di SMA N Banda Aceh ada beberapa problematika dalam pelaksanaan program BK di sekolah yaitu pelaksanaan layanan BK belum optimal salah satunya adalah layanan konseling yang belum menggunakan pendekatan, siswa yang tidak datang dengan sukarela, keterbatasan konselor dalam menguasai teknologi dalam membantu proses pelayanan bimbingan dan konseling. Problematika lain diungkapkan oleh Leksono (2017) di SMA Karangreja Kab. Purbalingga yaitu terdapat Guru BK bukan lulusan dari program studi Bimbingan dan Konseling, kurangnya kerjasama antara Guru BK dan Guru Matapelajaran, kurangnya fasilitas yang memadai dalam pelaksanaan layanan serta tidak tersedianya jam tatap muka untuk Guru BK. Khasanah (2019) mengungkapkan hal yang sama di SMA Ma'Arif Ngawi dalam pelaksanaan program BK tidak terdapat jam tatap muka bagi Guru BK untuk melaksanakan layanan klasikal, melainkan hanya melaksanakan layanan secara individual dan kelompok.

Meskipun melihat kebutuhan global saat ini bimbingan dan konseling sudah harus bergeser pada program BK Komprehensif, akan tetapi banyak ditemukan di lapangan masih terdapat sekolah-sekolah yang masih menerapkan program BK dengan pola lama yaitu pola 17 dan/atau 17+. Hal ini diungkapkan oleh Rozak, Fathurrochman \& Ristianti (2018) dalam penelitiannya di SMAN Simpang Semambang tentang Analisis Pelaksanaan Bimbingan Belajar dalam Mengatasi Kesulitan Belajar Siswa. Dalam penelitian tersebut dapat dilihat bahwa SMA Negeri Simpang Semambang masih menggunakan pola 17+ dalam melaksanakan program BK. Meskipun layanan tersebut telah dilaksanakan sesuai dengan perencanaan akan tetapi masih belum optimal. Faktor yang mempengaruhi hal tersebut antara lain: 1) kurangnya Guru BK/Konselor; 2) kurangnya intensitas layanan; 3) kurangnya minat siswa terhadap manfaat layanan; 4) kompetensi konselor; dan 5) faktor lain. Penelitian lain yang terkait ditemukan dalam penelitian Simamora \& Suwarjo (2013) di SMAN 4 Yogyakarta dimana dalam pelaksanaannya BK di sekolah belum menerapkan program BK Komprehensif dan nonguidance task.

Hal tersebut berkaitan dengan kinerja konselor sebagai salah satu sumber daya personil dalam pelaksanaan program. Ratnasari \& Herdi (2018) dalam penelitiannya terkait kinarja konselor berbasis ASCA Nasional mengungkapkan problematika dalam pelaksanaan program BK seperti masih ada peserta didik yang merasa takut untuk datang ke ruang BK serta fasilitas dalam melaksanakan layanan BK yang masih kurang memadai terjadi di SMAN 7 Kota Tasikmalaya. Untuk menangani permasalahan tersebut Guru BK menerapkan pedoman kinerja konselor berbasis ASCA. Dalam penelitia ini juga dungkapkan bahwa analisis terkait problematika dalam pelaksanaan program BK di sekolah dapat dianalisis melalui sumber daya personil serta fasilitas Bimbingan dan Konseling. Jika personil pelaksana baik serta sarana dan prasarana memadai maka program BK dapat terlaksana dengan optimal.

Adanya problematika diungkapkan dalam penelitian Pratiwi \& Muis (2013) di SMA Negeri 1 Menganti, SMA Negeri 1 Driyorejo dan SMA Al Azhar Menganti. Dalam penelitian tersebut diungkapkan bahwa di SMAN 1 Driyorejo masih mengalami problematika memperjuangkan pemberian jam masuk kelas bagi Guru BK. Di SMA Al Azhar Menganti terdapat problematika kurangnya personil bimbingan dan konseling serta di SMAN 1 Menganti mengalami problematika kerjasama tim rekan sejawat yang masih kurang dikarenakan tidak semua Guru BK berlatarbelakang pendidikan bimbingan dan konseling sehingga sulit untuk menyelaraskan kinerja karena dalam tim memiliki pemikiran yang berbeda-beda. Persepsi negatif peserta didik terhadap Bimbingan dan Konseling juga berpengaruh pada pelaksanaan program BK itu sendiri.

Astuti, Nursalim, Pratiwi \& Nuryono (2013) mengungkapkan hal yang sama tentang persepsi negatif peserta didik di SMA Kab. Lamongan. Dalam penelitian tersebut diungkapkan ada 15 kesalahpahaman peserta didik terhadap Bimbingan dan Konseling menurut Wardati \& Jauhari (Astuti, Nursalim, Pratiwi \& Nuryono, 2013) yaitu:

1) bimbingan dan konseling disamakan atau dipisahkan sama sekali dari pendidikan; 2) menyamakan pekerjaan konselor dengan pekerjaan dokter dan psikiater; 3) bimbingan dan konseling hanya mengatasi masalah yang berdifat insidental; 4) bimbingan dan konseling hanya terbatas pada siswa tertentu saja; 5) bimbingan dan konseling melayani "orang sakit" atau 
"kurang/tidak normal"; 6) pelayanan BK hanya terpusat pada keluhan awal saja; 7) bimbingan dan konseling mengatasi maslaah yang ringan saja; 8) guru BK sebagai polisi sekolah; 9) bimbingan dan konseling dipandang hanya sebagai pemberian nasehat; 10) bimbingan dan konseling bekerja sendiri tanpa harus bekerja sama dengan pihak lain; 11) konselor harus aktif sedangkan yang lain harus pasif; 12) menganggap pekerjaan BK dapat dilakukan oleh siapa saja; 13) menyamaratakan pemecahan masalah bagi semua konseli; 14) memusatkan usaha bimbingan dan konseling hanya pada penggunaan instrumen; dan 15) menganggap hasil bimbingan dan konseling harus segera terlihat.

Dalam penelitian tersebut terdapat tiga hambatan yang dialami oleh Guru BK SMA di Kabupaten Lamongan dalam mengubah persepsi peserta didik terhadap Bimbingan dan Konseling yaitu terdapat guru yang belum bersedia untuk berkolaborasi dengan konselor terkait banyaknya administrasi yang perlu diselesaikan, rendahnya pemahaman mengenai Bimbingan dan Konseling, dan Kepala Sekolah yang kurang peduli dengan Bimbingan dan Konseling.

Penelitian lain yang mengungkapkan mengenai persepsi peserta didik terhadap Bimbingan dan Konseling juga dilakukan oleh Busmayaril \& Heldayani (2016). Hasil dari penelitian tersebut mengenai persepsi peserta didik SMAN 1 Karya Penggawa terhadap Bimbingan dan Konseling yaitu: 1) layanan BK hanya untuk peserta didik yang bermasalah (nakal, membolos, tidak disiplin, dII); 2) layanan BK kurang berfungsi secara maksimal karena hanya berfokus pada fungsi pengentasan untuk siswa-siswa yang melanggar aturan; 3) kurangnya fasilitas yang memadai (tidak ada ruang khusus konseling); 4) kurangnya pemahaman peserta didik terkait bimbingan dan konseling sehingga hanya beberapa peserta didik yang memanfaatkan layanan bimbingan dna konseling; 5) kurangnya kompetensi Guru BK dalam melaksanakan layanan BK yang bersifat preventif dan pengembangan.

Penemuan penelitian lain terkait kesalahpahaman persepsi siswa terhadap Bimbingan dan Konseling juga diungkapkan oleh Kamil \& Ilham (2015) di SMA Negeri Pesisir Tengah yaitu peserta didik menganggap bahwa BK adalah: 1) supervisor disopliner terhadap peraturan sekolah; 2) menangani siswa yang mendapatkan masalah; 3) pedoman konseling sebagai badan keamanan pelajar atau sering disebut polisi sekolah. Lebih lanjut peneliti Noprita, Rosra \& Mayasari (2014) mengungkapkan problematika lain dalam pelaksanaan program BK di SMAN 1 Pesisir Tengah Kab. Pesisir Barat yaitu minimnya penguasaan guru BK dalam melaksanakan layanan, kurangnya alat perlengkapan dan anggara dana yang terbatas, kerjasama antara Guru BK dengan stake holder sekolah belum berjalan secara efektif serta belum adanya penjadwalan yang efektif untuk pelaksanaan BK di sekolah.

Dalam studi literatur juga ditemukan problematika lain dalam pelaksanaan program BK di sekolah yaitu tidak tersedianya kurikulum formal bimbingan dan konseling sehingga dalam pelaksanaan layanannya seringkali tidak terpogram dengan baik dan seringkali terjadi ketidaksesuaian dengan yang semestinya. Legowo, Susilo \& Kholili (2019) mengungkapkan bahwa ketidaktersediaan kurikulum formal bimbingan dan konsleing dalam hal penyelenggaraan layanan program BK menimbulkan salah satu akibat yaitu seringkali tidak tersedianya Jam Pelajaran (JP) untuk Guru BK. Problematika yang timbul tersebut sesuai dengan Rohman, Muspawi \& Martini (2017) mengungkapkan problematika pelaksanaan program BK di SMA N Kota Jambi yaitu program berjalan tidak sesuai dengan yang sudah direncanakan, layanan klasikal hanya diberikan ketika terdapat masalah atau ketika ada jam kosong saja, keterbatasan waktu yang dimiliki oleh guru BK, serta kurangnya anggaran untuk melaksanakan kegiatan pendukung Bimbingan dan Konseling.

Oleh karena itu dapat disimpulkan bahwa kurikulum dan program BK sangat perlu dikembangkan oleh Guru BK/Konselor melalui pendampingan ahli yang paham mengenai program yang sesuai dengan kebutuhan siswa. Berdasarkan berbagai problematika diatas, dapat disimpulkan bahwa diperlukan adanya upaya penanganan melalui program BK yang komprehensif dimana dalam pelaksanaannya melibatkan pihak lain yang terkait (stakeholder) untuk mencapai tujuan dari BK Komprehensif tersebut.

Berdasarkan hasil penelitian tersebut, peneliti membuat kategori problematika dalam pelaksanaan program BK komprehensif. Tinjauan yang digunakan peneliti yaitu: Komponen Program BK Komprehensif dan sumber daya. 
Ditinjau komponen programnya, problematika yang ditemukan antara lain : 1) Layanan dasar yang ditemukan problematika tidak ada jam masuk kelas/jam tatap muka untuk bimbingan klasikal dan tidak adanya jam atau alokasi waktu khusus untuk guru BK; 2) Layanan Responsif, terdapat problematika dimana dalam pelaksanaan konseling masih banyak Guru BK yang tidak menggunakan pendekatan dan masih banyak ditemukan peserta didik yang datang dengan tidak sukarela untuk melakukan konseling; 3) Perencanaan Individual, dalam penelitian ini peneliti tidak menemukan problematika yang terjadi; 4) Dukungan sistem, ditemukan problematika berupa kurangnya kerjasama guru BK dengan stakeholder dan kurangnya kemampuan konselor untuk meningkatkan kemampuan profesional.

Jika ditinjau dari sumber daya yang meliputi sumber daya personil, finansial, dan politik problematika yang ditemukan antara lain adalah sebagai berikut: 1) Rasio Guru BK dan siswa tidak sesuai standar ideal; 2) Kurangnya kompetensi dalam need assessment, program dan evaluasi; 3) Keterbatasan konselor dalam pemanfaatan teknologi; 4) Guru BK bukan bertalatar belakang pendidikan BK; 5) Non-guidance Task; 6) Kurangnya fasilitas yang memadai; 7) Kurangnya sarana \& prasarana yang memadai; 8) kurangnya anggaran untuk melaksanakan kegiatan pendukung BK; 9) Tidak adanya kurikulum yang pasti dalam melaksanakan program BK di sekolah.

Problematika dalam melaksanakan program BK di sekolah juga ditemukan pada aspek persepsi peserta didik terhadap pelaksanaan program atau layanan BK di sekolah. Problematika yang ditemukan antara lain: 1) Guru BK adalah polisi sekolah; 2) Layanan BK hanya untuk siswa bermasalah; 3) Layanan BK hanya untuk masalah-masalah yang insidental; 4) Kurangnya kompetensi Guru BK dalam melaksanakan layanan yang bersifat preventif dan pengembangan serta tak jarang masih cenderung menyalahkan peserta didik.

Persepsi stakeholder terhadap pelaksanaan program BK di sekolah ditemukan problematika sebagai berikut: 1) Guru BK tidak perlu bekerjasama dengan pihak lain; 2) Layanan BK hanya memberi nasehat; dan 3) Pekerjaan Guru BK dapat dilakukan oleh siapapun yang bukan lulusan BK.

Jika ditelaah lebih dalam Bimbingan dan Konseling merupakan bagian yang terintegrasi dalam sistem pendidikan di sekolah. Hal ini dapat dilihat dari tiga pilar yang mendukung berhasilnya sistem pendidikan, yaitu administrasi supervisi, sistem pengajaran, dan Bimbingan \& Konseling (Purwaningrum, 2018). Setiap bagian tersebut memiliki penanggung jawab masingmasing, akan tetapi dalam pelaksanaannya semua pihak stake holder sekolah harus saling bekerjasama dan konselor sebagai penanggung jawab di bidang Bimbingan dan Konseling agar dapat mewujudkan program BK yang memandirikan peserta didik. Selain itu, dalam program BK Komprehensif juga diperlukan suatu tatanan manajemen yang komprehensif pula.

Hal sesuai dengan penelitian Fanan \& Amriana (2019) mengenai manajemen BK komprehensif yang dilaksanakan di SMAN 1 Cisarua Bandung Barat. Dalam penelitian tersebut diungkapkan bahwa salah satu kompetensi dasar yang harus dikuasai oleh konselor yaitu manajemen Bimbingan dan Konseling.

Tujuan dari program BK komprehensif sendiri adalah upaya preventif permasalahan peserta didik dan membantu memilih tindakan yang dilakukan yang dapat mendukung perkembangan diri mereka. Sumaryanto (2016) dalam penelitiannya tentang implementasi program BK komprehensif di MAN 3 Yogyakarta (MAYOGA) mengungkapkan dua hal penting dalam penerapan program BK komprehensif, yaitu: bimbingan dan konseling komprehensif mengikuti pola separated curriculum yang berarti BK bukan merupakan kurikulum inti yang diajarkan kepada peserta didik dan memperoleh jam pelajaran mandiri seperti matapelajaran pada umumnya serta bimbingan konseling komprehensif terdiri dari komponen layanan dasar, layanan responsif, perencanaan individual dan dukungan sistem.

Tujuan dari program BK komprehensif tersebut dapat tercapai apabila memenuhi lima premis menurut Gysbers \& Henderson (2012) yaitu:

1) Tujuan dan bimbingan konseling bersifat kompatibel dengaan tujuan pendidikan; 2) Fokus utama layanan bimbingan dan konseling adalah mengawal perkembangan peserta didik melalui pemenuhan fasilitas peserta didik agar dapat tumbuh dan berkembang menjadi mandiri dan lebih optimal; 3) Program bimbingan dan konseling merupakan team building approach. Maksudnya adalah suatu tim yang bersifat kolaboratif antar staf; 4) Program bimbingan dan konseling 
merupakan sebuah proses yang tersusun secara sistematis dan dikemas melalui tahap-tahap perencanaan, desain, implementasi, evaluasi, dan tindak lanjut; 5) Program bimbingan dan konseling harus dikendalikan oleh kepemimpinan yang memiliki visi dan misi yang kuat mengenai bimbingan dan konseling.

Prinsip dalam manajemen layanan BK meliputi: planning, organizing, staffing, leading \& controlling. Upaya yang ditawarkan dalam menghadapi berbagai problematika dalam melaksanakan program BK di sekolah yaitu adanya dukungan Kepala Sekolah dan dinas setempat sebagai pihak yang mengeluarkan kebijakan pada sektor pendidikan.

Selain itu upaya yang dapat dilakukan yaitu setiap Guru BK dapat meningkatkan kinerja dengan membina sikap disiplin, mendukung visi misi sekolah, menetapkan target kerja, dan menyusun kurikulum BK uang mendukung kemajuan sekolah. Selain itu, Guru BK juga dapat meningkatkan kualitasnya melalui kegiatan seminar, workshop, MGBK dan kegiatan ilmiah untuk meningkatkan kompetensinya, dan juga adanya upaya kooperatif antara Guru BK dan sekuruh stake holder agar program BK dapat terlaksana dengan baik.

Upaya lain yang dapat dilakukan dalam menghadapi problematika dalam pelaksanaan program BK di sekolah yaitu Guru BK atau konselor melakukan pendekatan dan memberikan pemahaman terkait bimbingan dan konseling baik kepada Guru lain maupun kepada peserta didik, mengadakan staf administrasi khusus untuk BK, serta melakukan pendekatan melalui Kepala Sekolah terkait memberikan pemahaman terkait bimbingan dan konseling mengingat sebagai orang yang berpengaruh dalam sekolah, serta Guru BK juga perlu meningkatkan kompetensi diri melalui kegiatan dukungan sistem dengan melibatkan pihak lain dalam upaya mengubah persepsi negatif terhadap bimbingan dan konseling.

\section{Simpulan}

Hasil temuan dari penelitian Systematical Literature Review (SLR) ini yaitu terdapat berbagai macam problematika pada pelaksanaan program Bimbingan dan Konseling di Sekolah khususnya di Sekolah Menengah Atas (SMA). Problematika yang dialami dalam pelaksanaan program BK di SMA diantaranya yaitu : Guru BK belum mendapatkan proporsi waktu mengajar yang optimal, belum adanya kerjasama dengan pihak sekolah, rendahnya sosialisasi Bimbingan dan Konseling oleh Guru BK kepada perserta didik, terdapat sekolah yang masih menerapkan Bk pola lama yakni BK Pola 17+, terdapat prresepsi negatif daru perserta didik yang masih merasa takut untuk bertemu dengan Guru BK, belum optimalnya dalam mengoptimalkan fasilitas pada layanan Bimbingan dan Konseling di Sekolah.

Peran Guru BK dan kolaborasi antara pihak lain yang terkai pelaksanaan program Bimbingan dan Konseling dalam upaya mencapai tujuan dari BK Komprehensif itu sendiri. Dalam pelaksanaan program BK terdapat dukungan sistem yang optimal dalam pelaksanaan prorgam BK karena sebagai optimalisasi pada layanan program BK yang diberikan kepada perserta didik di SMA. Saran untuk peneliti selanjutnya adalah diperlukannya adanya upaya penanganan melalui program BK yang Komprehensif dimana dalam pelaksanaannya melibatkan pihak lain yang terkait (stakeholder) untuk mencapai tujuan dari BK komprehensif itu sendiri.

\section{Ucapan Terima Kasih}

Pada kesempatan ini kami mengucapkan terimakasih kepada Ma'rifatin Indah Kholili, M. Pd. Selaku Dosen Program Studi Bimbingan dan Konseling FKIP UNS yang sejak awal memberikan bimbingan, saran, serta kritik selama proses penyusunan artikel hingga sebelum diterbitkan. Selain itu kepada tim peneliti yang telah bekerja keras dalam menyusun dan menyelesaikan artikel ini serta kepada pihak-pihak lain di luar tim peneliti yang turut serta dalam membantu menghimpun sumber referensi yang relevan dengan judul penelitian kami. 


\section{Daftar Rujukan}

Astuti, Nursalim, Pratiwi \& Nuryono. (2013). Pelaksanaan Bimbingan dan Konseling untuk Merubah Persepsi Negatif Siswa di Sekolah Menengah Atas di Kabupaten Lamongan. Jurnal BK UNESA. 03(01). Hal: 271-280

Bhakti. C.P. (2017). Program Bimbingan dan Konseling Komprehensif untuk Mengembangkan Standar Kompetensi Siswa. Jurnal Konseling Andi Matappa. 1(1).

Busmayaril \& Heldayani. (2016). Persepsi Peserta Didik terhadap Pelaksanaan Bimbingan dan Konseling di Sekolah Menengah Atas Negeri 1 Karya Penggawa Kabupaten Pesisir Barat. KONSELI: Jurnal Bimbingan dan Konseling. 03(1). Hal: 11-18

Corey. G. (2016). Theory and Practice of Guidance and Counseling $9^{\text {th }}$ Edition. Boston : Cengage Learning.

Depdiknas. (2008). Penataan Pendidikan Profesional Konselor dan Layanan Bimbingan dan Konseling dalam Jalur Pendidikan Formal. Jakarta : Depdiknas.

Fanan, M.A. \& Amriana. (2019). Manajemen Komprehensif (Studi Layanan Bimbingan dan Konseling di SMA Negeri 1 Cisarua Bandung Barat). Jurnal Bimbingan dan Konseling Islam. 9(01). Hal: 91-97

Gysbers, N. C., \& Henderson, P. (2012). Developing \& Managing Your School Guidance \& Counseling Program (5th ed). Alexandria, VA: American Counseling Association.

Kamil, B. \& Ilham, P. (2015). Persepsi Siswa Tentang Pelaksanaan Bimbingan dan Konseling di Sekolah Menengah Atas. Konseli:Jurnal Bimbingan dan Konseling. 02 (2). Hal: 32-36

Khasanah, K. (2019). Manajemen Bimbingan dan Konseling di SMA Ma'Arif Ngawi. Al-Tazkiah. 8(1). Hal: 29-50

Legowo, E., Susilo, A.T. \& Kholili, M.I. (2019). Urgensi Program Serta Kurikulum Bimbingan dan Konseling. G-COUNS. 4(1). Hal: 113-118

Leksono, B.B. (2017). Manajemen Bimbingan dan Konseling di Sekolah Menengah Atas Negeri Karangreja Kabupaten Purbalingga.[tesis]. Jawa Tengah (ID): Universitas Agama Islam Negeri Purwokerto

Mauliza, R., Dahliana Abd \& Martunis. (2018). Profil Guru BK Tersertifikasi dalam Penyusunan dan Pelaksanaan Program Bimbingan dan Konseling di SMA Negeri Banda Aceh. Jurnal IImiah Mahasiswa Bimbingan dan Konseling. 3(2). Hal: 50-57

Noprita, Rosra, W. \& Mayasari, S. (2014). Kendala Pelaksanaan Kegiatan Bimbingan dan Konseling di SMA Negeri 1 Pesisir Tengah Kabupaten Pesisir Barat Tahun Pelajaran 2013/2014. ALIBKIN (Jurnal Bimbingan Konseling). 3(3)

Permana, E.J. (2015). Pelaksanaan Layanan Bimbingan dan Konseling di Madrasah Aliyah Negeri 2 Banjarnegara. Psikopedagogia. 4(2). Hal: 143 - 151

Pratiwi, J.R.E. \& Muis, T. (2013). Evaluasi Pelaksanaan Program Bimbingan dan Konseling di SMAN 1 Menganti, SMAN 1 Driyorejo, dan SMA Al Azhar Kabupaten Gresik. Jurnal BK UNESA. 3(1). Hal: 427-436

Purwani, E., Nita, R.W. \& Monalisa. (2017). Kendala Guru Bimbingan dan Konseling dalam Pelaksanaan Layanan Informasi di SMA Negeri 7 Kerinci. (online). http://repo.stkip-pgrisumbar.ac.id/id/eprint/1188/ diakses pada tanggal 26 November 2020

Purwaningrum, R. (2018). Bimbingan dan Konseling Komprehensif sebagai Pelayanan Prima Konselor. Jurnal Ilmiah Konseling. 18 (1). Hal: $18-27$

Puspitaningrum, L., Dahlan, S. \& Widiastuti, R. (2013). Pelaksanaan Pelayanan Dasar Bimbingan dan Konseling pada SMA di Kota Metro Tahun Ajaran 2012/2013. ALIBKIN: Jurnal Bimbingan dan Konseling. 2(1)

Putri, R., Hastuti, T. \& Nurhuda. (2018). Analisis Pelaksanaan Bimbingan dan Konseling (Studi Kasus pada Mata Pelajaran Ekonomi Kelas X IPS SMAN 1 Peranap Kabupaten Indragini Hulu). PeKA: Jurnal Pendidikan Ekonomi Akuntansi FKIP UIR. 6(1). Hal: 31-37

Rahman, K.A., Muspawi, M. \& Martini, T. (2017). Manajemen Bimbingan dan Konseling di SMA Negeri. Jurnal Administrasi Pendidikan. XXIV(1). Hal: 41-47 
Ratnasari \& Herdi. (2018). Kinerja Konselor dalam Pelaksanaan Manajemen Program Bimbingan dan Konseling Berbasis ASCA Nasional. Jurnal Penelitian Bimbingan dan Konseling. 3(2). Hal: 134-142

Rozak, A., Fathurrochman, I. \& Ristianti, D.H. (2018). Analisis Pelaksanaan Bimbingan Belajar dalam Mengatasi Kesulitan Belajar Siswa. Jurnal of Education and Instruction. 1(1). Hal: 10-20

Simamora, A.L. \& Suwarjo. (2013). Manajemen Bimbingan dan Konseling di SMAN 4 Yogyakarta. Jurnal Akuntabilitas Manajemen Pendidikan. 1(2). Hal: 190-204

Sumaryanto. (2016). Implementasi Program Bimbingan dan Konseling Komprehensif di Madrasah Aliyah Negeri III Yogyakarta (MAYOGA). Online. http://ejournal.iaingawi.ac.id/index.php/almabsut/article/download/130/92 diakses pada tanggal 16 November 2020

Zamroni, E., \& Rahardjo, S. (2015). Manajemen Bimbingan dan Konseling Berbasis Permendikbud Nomor 111 Tahun 2014. Jurnal Konseling GUSJIGANG. 1(1).

\section{Competing interests:}

The authors declare that they have no significant competing financial, professional or personal interests that might have influenced the performance or presentation of the work described in this manuscript. 